\title{
INTERCULTURAL RELATIONS AS A DIALOGUE OF CONFESSIONS IN SOCIAL SPACE AND CYBERSPACE OF MULTICULTURAL RUSSIA
}

\author{
(C) Asiyat M. Buttayeva, Aslan M. Aslanov, Zumrud S. Suleimanova
}

\author{
Dagestan Institute of Humanities, Dagestan State University, \\ Republic of Dagestan, Makhachkala, Russian Federation \\ aslan1980@mail.ru, zumrud-suleyman@bk.ru
}

The dialogue of confessions in the context of intercultural relations certainly plays a special role in the history of the world civilization in general, and in particular of countries with a multicultural and multi-confessional component. Therefore, now, in the period of globalization, one of the main tasks of modern Russian society is to preserve multicultural and multi-confessional historical heritage of all the peoples of Russia, to prevent possible conflicts, and to create an atmosphere of respect for cultural values in society. The study addresses the problem of a dialogue of cultures in the traditional "dimension" and in "cyberspace". It is noted that the idea of a dialogue as a form of intercultural interaction makes it possible to consider the problems of inter-confessional relations in the system of culture. The attempt is made to determine the name of the digital environment - "cyberworld", and to introduce it into scientific circulation as a philosophical category for denoting the digital environment. An approach to understanding intercultural relations as a dialogue of confessions is proposed, which allows us to consider religion as a unifying factor of cultures. Digitalization promotes a dialogue both inter-confessional and intercultural, creating an additional environment - a cyber world with an intensive speed of information flow; to avoid assimilation of religions in the flow of information in cyberspace, cross-cultural and religious literacy is necessary. Religion is a factor that unites cultures and which consolidates in the inter-confessional dialogue, both in social and in cyberspace.

Key words: dialogue, culture, religion, cyberspace, confessions.

[А.М. Бутmаева, А.М. Асланов, 3.С. Сулейманова Межкультурные отношения как диалог конфессий в социальном пространстве и киберпространстве поликультурной России]

Диалог конфессий в контексте межкультурных отношений безусловно занимает особую роль в истории мировой цивилизации в целом, и в частности, стран с поликультурной и поликонфессиональной составляющей. Следовательно, сейчас, в период глобализации, к числу главных задач современного Российского общества относится сохранение поликультурного и поликонфессионального исторического наследия всех народов России, предотвращение возможных конфликтов, формирование в социуме атмосферы уважения к культурным ценностям. В исследовании затрагивается проблема диалога культур в традиционном «измерении» и в «киберпространстве». Отмечено, что идея диалога как фрормы межкультурного взаимодействия даёт возможность рассматривать проблемы межконфессиональных отношений в системе культуры. Сделана попытка определить название цифровой среде «кибермир», и ввести её в научный оборот как философскую категорию для обозначения цифровой среды. Предложен подход к пониманию межкультурных отношений как диалога конфессий, что позволяет рассматривать религию как объединяющий фактор культур. Показано, что цифровизация способствует диалогу как межконфессиональному, так и межкультурному, создавая дополнительную среду кибермир с интенсивной скоростью информационного потока. Во избежание ассимиляции религий в потоке информации в киберпространстве необходима кросскультурная и религиозная грамотность. Подчеркнуто, что именно религия есть фрактор, объединяющий культуры и консолидирующийся в межконфессиональном диалоге как в социальном, так и киберпространстве.

Ключевые слова: диалог, культура, религия, киберпространство, конфессии.

Asiyat M. Buttayeva - Ph.D. (Advanced Doctorate) in Philosophy, Professor, Dagestan Institute of Humanities, Makhachkala, Republic of Dagestan, Russian Federation.

Aslan M. Aslanov - Ph.D. student, Dagestan State University, Makhachkala, Republic of Dagestan, Russian Federation.

Zumrud S. Suleimanova - Ph.D. student, Dagestan State University, Makhachkala, Republic of Dagestan, Russian Federation. 
Буттаева Асият Магомедовна - доктор философских наук, профрессор, Дагестанский гуманитарный институт, г. Махачкала, Республика Дагестан, Российская Федерация.

Асланов Аслан Махмудович - аспирант, Дагестанский государственный университет, г. Махачкала, Республика Дагестан, Российская Федерация.

Сулейманова Зумруд Сулеймановна - аспирант, Дагестанский государственный университет, г. Махачкала, Республика Дагестан, Российская Федерация.

As an integral attribute of the condition of unity of general culture, the dialogue ensured the coexistence and mutual enrichment of many specific ethnic, social and confessional groups. Therefore, now, during the period of globalization, the preservation of the multicultural and multi-confessional historical heritage of all the peoples of Russia, the prevention of possible conflicts, the formation of an atmosphere of respect for their cultural values in society, are among the main tasks of modern Russian society.

In addressing the issue of inter-confessional relations, most scientists focus on their close relationship with interethnic relations, and the problems of the interaction of religion and culture, as well as the role and possibilities of the latter in harmonizing inter-confessional relations, often remain outside the scope of the study, which makes it necessary to study and analyze these relations through the lens of culture. Culture is an environment in which the formation of a person with a number of qualities takes place: creative activity and independence, patriotism and tolerance, presence and awareness of the value of the meanings of life, intellectual, moral and aesthetic foundations, mental and spiritual maturity, the desire for self-knowledge, self-education and self-realization, etc. The formation of all these qualities is based on the development of cultures: the individual itself, the culture of society, and finally, the culture of all mankind. sion."

Dialogue of cultures in a multicultural environment in the traditional "dimen-

The dialogue of cultures is a diverse phenomenon and involves the study of such aspects as differences in the interethnic, social, demographic, gender, linguistic order.

What is a dialogue? Representatives of various schools and fields, for example, M.M. Bakhtin, V.S. Bibler, M. Buber, F. Gogarten, F. Rosenzweig, E. Rosenstock-Huessy, G. Cohen, F. Ebner, E. Husserl, M. Heidegger, C. Lévi-Strauss, N.S. Trubetskoy and others, were engaged in the search for an answer to this question in the history of philosophy because the complexity and multidimensional nature of this category gives inexhaustible opportunities for its research.

In the meantime, it must be emphasized that there is no single concept of the dialogue of cultures.

So, for example, N.A. Velikaia considers that: "The dialogue, being a phenomenon "with a lot of senses"... includes spiritual and moral moments that contribute to the establishment of understanding and unity not only at the level of interpersonal, but also intercultural communication. The main category that determines the essence of the dialogue of cultures is understanding, which contributes to the learning of the inner world of culture in terms of its value" [5].

A.M. Buttaeva considers the "dialogicity" of each culture to be a key feature that makes it possible to understand it precisely as a culture, while this dialogicity, in her opinion, is understood "in two aspects: on the one hand, the internal ability to be removed from itself, not to coincide with itself, to be dialogic in relation to itself and, on the other hand, the existence of each culture on the border with other cultures" [3, p. 22].

The dialogue, in which the recognition and self-recognition of cultures, mutual enrichment and stimulation of their development take place, creates the background itself, on the quality of which depends the clarity of the contours of the interacting systems. At the same time, inter-confessional relations, on the one hand, can be considered as a specific dialogue 
of cultures, and, in addition, in such a meeting of cultures there are theological and everyday levels, each of which has specific features.

And so, the idea of a dialogue as a form of intercultural interaction makes it possible to consider the problems of inter-confessional relations in the system of culture. With this approach, namely, the dialogue as a value or recognition of the value of another, the dialogue of cultures is the basis for solving both intercultural and inter-confessional problems. Polyphony of cultures and their identity established during centuries, revealed in the dialogue, is the property of modern civilization, and the understanding of inter-confessional relations as a dialogue of cultures will make it possible to find not only ways to preserve the multi-confessional historical heritage, but also to prevent possible conflicts in the future.

\section{Digitalization of culture and religion. Dialogue in cyberspace.}

All of the above relates to the dialogue of cultures in a multicultural environment in the traditional "dimension". Today, the dialogue of cultures and the multicultural environment itself are undergoing transformation under the onslaught of rapid changes in the form of rapid globalization, informatization, digitalization of society and codification.

Spatial dimensions of the socio-cultural environment take on different forms, the dialogue of cultures, following the cultural environment goes into other dimensions, into a kind of "cloud" - "cyberspace".

Cyberspace covered the space of everyday interaction in the real world as if a wave and covered a huge layer of individuals and organizations, in the light of recent events related to COVID-19. One after another, countries closed borders, declared a quarantine and a person was forced to "be locked up," after the general director of the World Health Organization Tedros Adhanom Ghebreyesus at a briefing in Geneva on March 11, 2020, said that the spread of the new coronavirus in the world has become a pandemic [3]. And as a result, during the period of isolation there is an increase in the use of digital means by the society by which people interact with each other and with the world around them. The sociocultural significance of digital means, regardless of their merits and shortcomings, is obvious. "With their spread, there are changes that affect the daily life of people, established cultural hierarchies, the ways in which people interact with each other and with the world around them. The system of formation of cultural experience as a whole, all basic spheres of culture have been changing" [4].

In the cultural and philosophical aspect, digital culture is interpreted as a new form of being, as the "third" world: "A man acquires a new being in the virtual space, while the value of the real world gradually shifts towards the virtual. The boundary between them is blurred, illusiveness in relation to being is increased" [5, p.58]. If you try to determine the name for this world, then it should sound "cyberworld". And if you try to determine the place for this world, then we can say that it is between the (Platonic) world of ideas and the world of things. This world, unlike the "world of things," is not felt, therefore, at least in one category it does not correspond to it. And at the same time, it is knowable for the mind, therefore, it corresponds to the "world of ideas" at least in one category. Saying "between" does not mean that the "cyberworld" claims ideality, and other categories of the world of ideas, but that it is located in the periphery of the "world of things", as a continuation of its natural habitat.

As for the religious sphere, it is not the exception of revolutionary changes. Currently, the sphere of religion, in its forms and manifestations, is undergoing transformation under the influence of digitalization, forming a new sphere of reality. The proof of this is the special applications for gadgets that appeared several years ago, and are successfully used by practicing believers to make themselves more consistent and enlightened in the field of religion.

Nowadays, there are numerous applications for practitioners of different confessions, for example: for Christians, Muslims, Jews, etc. 
Further, according to the scientists, the mode of "religion online," namely, live broadcasts of sacred services, other religious rites and ceremonies are considered to be a common phenomenon [17]. We also note that there are numerous sites, and countless bloggers engaged in missionary, preaching, and other activities. In general, there is a transformation of previous religious practices, which "is viewed positively not by everyone. When the usual stereotypical image of religion breaks up, it is perceived almost as a disaster and as a death of foundations" [14].

But, there are those who share the opinion that "the Internet environment by no means absorbs or substitutes for the religious-sacred dimension, but finds in the modern media sphere new and more effective ways to translate the semantic components of religious experience into the external social space, that is, from the position of this approach it is correct to consider modern media as a functional complement to traditional forms of religious communication" [15].

The phenomenon of "digital religion" is a synergistic, dynamically expanding spiritual space in the cyberworld. Therefore, the problem of the dialogue of confessions in cyberspace is that not to lose the main dogmas of religions in this synergy, but to preserve the uniqueness of each confession. The dialogue should be built as a consolidation, not as an assimilation.

\section{Religion as a unifying factor of cultures and as a consolidant of confessions.}

As for religion and culture in general, we emphasize that religion is a part of culture, and culture in turn is reflected in religion. Thus, intercultural and inter-confessional relations are closely interwoven, as well as identical, with the exception of a number of factors, the main of which can be called national character. Religion, unlike culture, has no national character, the boundaries of which are defined by the boundaries of a certain nation and people. Religion encompasses national ethnic pluralism and multiculturalism. With this approach, religion is more of a unifying factor, and intercultural relations depend largely on the interreligious dialogue.

This raises the question of what is there, inter-confessional relations through the dialogue of cultures or intercultural relations through the dialogue of confessions.

In many ways, the answers to this question depend on the position from which we approach the question of religion. Of course, we still have the prevailing in Western international politics, repeatedly refuted by historical facts, but the "lively" secular hypothesis that religions are a source of disagreement between the individuals and the ethnocultural component, and inevitably provoke conflicts, clashes of civilizations. In this regard, it is proposed to reduce the presence and the influence of the religious factor in all peacekeeping initiatives, despite the fact that for three decades many scientists, including Western ones, have been criticizing this hypothesis, as noted by S.V. Melnik.

Moreover, at critical, turning points in the development of civilization, it was religion that acted as a powerful ideological tool for managing society, since it "contains a huge value potential for peacemaking and can act as a serious unifying social tool" [10].

The inter-confessional dialogue, in turn, makes it possible to mitigate or even completely relieve tension in relations and contradictions between different cultures of peoples and countries.

So, in the epistle from Paul (To the Colossians) "(8) And now set aside everything: anger, rage, malice, abuse, foul language ... (11) where there is neither Hellene nor Jew nor circumcision, nor uncircumcision, barbarian, Scythian, slave, freeman, but everything is God and God is in everything" [2].

As for the Quran, it contains many ayats addressed to believers that life-building should be in line with tolerance, mildness, condescension [1].

Moreover, according to the lines of the Holy for Muslims Scripture, the meaning of the existence of multiculturalism is a dialogue: "O people! Indeed, we created you from a man 
and a woman and made you peoples and tribes so that you would recognize each other..." [8].

Regarding the inter-confessional dialogue, there are a lot of ayats of the Quran. As an example, we cite one of them, in which Allah, addressing believers, says: "Tell (oh, believers) (those Jews and Christians): "We believed in Allah (we recognize only Allah as God) and in what was sent to us (Quran) ... and what was given to the prophets from their God (former Scriptures). We do not distinguish between anyone of them (We are not such that we recognize some prophets, and we do not recognize others, as the Jews and Christians do), and we devote ourselves to Him [9].

In the hadiths (sayings) of the Prophet (let Allah bless him and welcome him) there are also a lot of appeals to Muslims regarding morality, tolerance, mildness, condescension to the representatives of different confessions and cultures, which contributes to the successful implementation of the ideas of the interreligious dialogue contained in the Quran. Moreover, "the constitution of Medina indicates that it was the prophet Muhammad (let Allah bless him and welcome him) who was one of the first to lay the ideological foundation for the formation of the concept of "civic identity" as an integral condition for the peaceful existence of people and ethnic groups in a multi-ethnic and multi-confessional country" [1, p. 30].

It should be noted that this is the first official document (containing the idea of the interconfessional dialogue), the provision of which was adopted by representatives of different confessions and successfully implemented. This is a kind of "prototype" of documents of our times regarding this reflection, for example, such as: "Social Doctrine of Russian Muslims" and "Fundamentals of the Social Concept of the Russian Orthodox Church" [15].

The most striking example of the inter-confessional dialogue is the activity of the Interreligious Council of Russia (ICR), formed on 23 December 1998 at a joint meeting of the heads of the Orthodox, Muslim, Jewish and Buddhist religious communities of the country [11].

The position of ICR members is based on the fact that society must be built on a spiritual and moral basis and that the dialogue of confessions, the consolidation of believers and the speech of religious leaders with an agreed position are actions which have great potential for peacemaking and spiritual recovery of society.

Since its foundation, ICR has expressed the above position on a variety of issues of concern of society. ICR "keeps its finger on the pulse" of the religious life of society. So, for example, on 30 July 2020 the document "Living Together in Peace and Respect" appeared on the main webpage, which contains calls from religious leaders expressed at the World Conference "Religions for Peace" for balance, peace, cooperation on the new status of the Museum of Hagia Sophia. The context of the appeal indicates that the issue of status is sidelined compared to the question of a universal world, where the main position is expressed in the words... "We advocate universal spirituality and peace, which goes beyond one religion, one race, one gender, one ethnic group, one emblem, one institution and one nation..." [16].

Emphasizing universal spirituality and peace, Spiritual Directorate of the Muslims of the Russian Federation, called the new status of Hagia Sophia a victory of Christians, Jews and Muslims. In particular, the first deputy head of Spiritual Directorate of the Muslims of the Russian Federation, Damir Mukhetdinov, believes that... "this is a positive transformation for Jews, Muslims and Christians, since now they will serve single for all Abrahamic religions God... Hagia Sophia is the house of God, in which now there are not just museum exhibits, but there will be the praise of God, one for Jews, Christians and Muslims. Therefore, I believe that this (returning of the Hagia Sophia Museum to the status of a mosque) is a victory for all believers, Christians, Jews, and Muslims... " He also emphasized that "millions of people will have the opportunity to visit this house of God for free, to admire its style, beautiful images, including Christian ones" [6]. 
In this interview in the Russian state news agency RIA Novosti, Mukhetdinov expressed surprise at the position (indignation) of some Orthodox hierarchs regarding this issue. And indeed, does the cultural value of the object suffer from religious rites? On the contrary, the object of culture is surrounded by a spiritual aura. Moreover, given that culture is perceived at a deep sensual level, it is perceived even brighter from spiritual feeding. This is a national treasure and it has not ceased to be a national treasure because of the change of its status. In our opinion, there is no place for any indignation. After all, the doors have been opened for everyone, and even those who were not able to pay for visiting, when it was with its previous status (museum status). Now Hagia Sophia is not just a museum, and not even just a temple or a mosque, it is a model of the plexus of culture and religion, a cultural "field" of the interreligious dialogue.

\section{Conclusion.}

Summarizing the above, digitalization promotes both the inter-confessional dialogue and intercultural one, creating an additional environment - cyberspace (cyberworld) with an intensive speed of information flow. However, in order to avoid assimilation in the flow of information in cyberspace, cross-cultural literacy (awareness of differences in ideas, customs, traditions inherent in different cultures) is necessary, and religious literacy, which at least allows to preserve the basic foundations of religion.

It is cross-cultural and religious literacy that will preserve confessional and cultural diversity determining the uniqueness of Russia with a help of a special wealth and common property. However, if cyberspace itself becomes the source of information for improving this literacy, then what the dialogue will be, the question remains open.

As for the reflection, intercultural relations as a dialogue of confessions, or inter-confessional relations as a dialogue of cultures, it is religion that unites cultures and consolidates in the inter-confessional dialogue, both in social space and in cyberspace.

\section{Лumepamypa}

1. Асланов А.М., Буттаева А.М. Ислам и духовное наследие мусульман России как фактор духовной безопасности: на примере Дагестана // Сборник материалов VI Международной научно-практической конференции. Грозный. 2019. С. 22-31 [Электронный ресурc] URL: https://www.elibrary.ru/item.asp?id =41530314 (дата обращения: 07.08.2020).

2. Азбука веры» Библия» Апостола Павла послание к Колоссянам 2:8-3:11. [Электронный ресурc] URL: azbyka.ru/biblia/?Col.3:11\#sel =36:12,36:12 (дата обращения: 07.08.2020).

3. Буттаева А.М. Специфика духовного бытия человека в условиях поликультурной среды: Махачкала, 2003. 162 с. С. 22.

4. Всемирная конференция «Религии за мир» выступила с заявлением по поводу храма Святой Софии: «Живя вместе в мире и уважении». [Электронный ресурс] URL: http://interreligious.ru/news/зарубежный/ mezhreligioznyy-dialog-zarubezhom_490.html (дата обращения: 14.09.2020).

5. Великая Н.A. Диалог культур в поликультурном пространстве современной России. Автореферат диссертации. Ставрополь, 2009.

6. ДУМ РФ: новый статус Святой Софии - победа христиан, иудеев и мусульман - РИА новости [Электронный ресурc]. URL: https://ria.ru /20200713/1574283136.html (дата обращения: 14.09.2020). 
7. Иванов А.В. Цифровая религия // Известия Саратовского университета. Сер. Философия. Психология. Педагогика. 2018. Т. 18, вып. 4. С. 377-381. [Электронный ресурc]. URL: https://cyberleninka.ru/article/n/tsifrovaya-religiya-1 (дата обращения: 20.08.2020).

8. Коран, сура: 49 «Аль-Худжурат»: 13.

9. Коран онлайн. Аль-Бакара (Корова), 136. [Электронный ресурс] URL: https://quran-online.ru/2:136 (дата обращения: 07.08.2020).

10. Мельник С.В. «Национальный вопрос» в межрелигиозном диалоге. Институт научной информации по общественным наукам РАН. М., 2019. [Электронный pecypc]. URL: https://cyberleninka.ru/article /n/natsionalnyi-vopros-vmezhreligioznom-dialoge (дата обращения: 25.08.2020).

11. Межрелигиозный совет России, (MCP) [Электронный ресурc]. URL: http://interreligious.ru/about/ (дата обращения: 14.08.2020).

12. Риа новости. ВОЗ объявила о пандемии коронавируса. [Электронный ресурс]. URL: https://ria.ru/20200311/1568455428.html (дата обращения: 14.08.2020).

13. Социальная доктрина российских мусульман. [Электронный ресурс]. URL: https://islam-today.ru/socialnaa-doktrina-rossijskih-musulman/ (дата обращения: 21.08.2020).

14. Сергеева И.Л. Трансформация массовой культуры в цифровой среде // Культура и цивилизация. 2016 Т. 6N 6А. С. 58.

15. Смирнов М.Ю. Цифровизация как «обнуление» религий. [Электронный ресурс]. URL: https://cyberleninka.ru/article/n/ tsifrovizatsiya-kak-obnulenie-religiy (дата обращения: 20.08.2020).

16. Соколова Н.Л. Цифрровая культура или культура в цифровую эпоху // Международный журнал исследований культуры. 2012. N 3. С. 6. [Электронный ресурс]. URL:

http://www.culturalresearch.ru/files/open_issues/03_2012/IJCR_03\%288\%29_2012. pdf (дата обращения:07.09.2020).

17. Цифровая религия. Проникновение церкви в онлайн. [Электронный ресурс]. URL: https://novate.ru/blogs/190313/22688/ (дата обращения: 14.08.2020).

\section{References}

1. Aslanov A.M., Buttayeva A.M. Islam i dukhovnoe nasledie musulman Rossii kak faktor dukhovnoi bezopasnosti: na primere Dagestana [Islam and the spiritual heritage of Muslims of Russia as a factor of spiritual security: on the example of Dagestan]. The article in the sourcebook of the VI International Scientific and Practical Conference. Language: Russian. Grozny. 2019. pp. 22-31. Available at: https://www.elibrary.ru/item. asp?id $=41530314$ (accessed 7 August 2020).

2. Azbuka very 'Bibliia' Apostola Pavla poslanie k Kolossianam [The Bible of Faith » the Bible » the epistle from Paul to the Colossians] 2:8-3:11 Available at: azbyka.ru/biblia/? Col.3: 11 \# sel = 36: 12.36: 12 (accessed 7 August 2020). 
3. Buttayeva A.M. Spetsifika dukhovnogo bytiia cheloveka v usloviiakh polikulturnoi sredy [The specifics of the spiritual existence of a person in a multicultural environment]: Makhachkala, 2003. 162 p. 22 p. (in Russian).

4. Vsemirnaia konferentsiia "Religii za mir vystupila s zaiavleniem po povodu khrama Sviatoi Sofii: "Zhivia vmeste v mire i uvazhenii" [The World Conference "Religions for Peace" issued a statement on the temple of Hagia Sophia: "Living together in peace and respect."] Available at: http://interreligious.ru/news/зарубежный/ mezhreligioznyy-dialog-za-rubezhom_490.html (accessed 14 September 2020).

5. Velikaya N.A. Dialog kultur v polikulturnom prostranstve sovremennoi Rossii [Dialogue of cultures in the multicultural space of modern Russia]. Dissertation abstract. Stavropol, 2009.

6. DUM RF: novyi status Sviatoi Sofii - pobeda khristian, iudeev i musulman - RIA novosti [Spiritual Directorate of the Muslims of the Russian Federation: the new status of Hagia Sophia, the victory of Christians, Jews and Muslims, RIA news]. Available at: https://ria.ru/ 20200713/1574283136 .html (accessed 14 September 2020).

7. Ivanov A.V. Tsifrovaia religiia [Digital religion]. Izvestiya of Saratov University. Series: Philosophy. Psychology. Pedagogics. 2018. V. 18, Issue. 4. pp. 377-381. Available at: https://cyberleninka.ru/article/n/tsifrovaya-religiya-1 (accessed 20 August 2020).

8. Koran, sura: 49 "Al-Khudzhurat": 13 [Quran, Surah: 49 "Al-Khujurat", 13].

9. Koran onlain. Al-Bakara (Korova), 136. [Online Quran. Al-Bakara (Cow), 136]. Available at: https://quran-online.ru/2: 136 (accessed 7 August 2020).

10. Melnik S.V. "Natsionalnyi vopros" v mezhreligioznom dialoge. Institut nauchnoi informatsii po obshchestvennym naukam RAN ["National Question" in interreligious dialogue. Institute of Scientific Information on Social Sciences of the Russian Academy of Sciences]. Moscow. 2019. Available at: https://cyberleninka.ru/article/n/natsionalnyi-vopros-v-mezhreligioznom-dialoge (accessed 25 August 2020).

11. Mezhreligioznyi sovet Rossii, (MSR) [Interreligious Council of Russia, (ICR)]. Available at: http://interreligious.ru/about/ (accessed 14 August 2020).

12. Ria novosti. VOZ obiavila o pandemii koronavirusa. [RIA Novosti. WHO has announced a coronavirus pandemic]. Available at: https://ria.ru/20200311/1568455428.html (accessed 14 August 2020).

13. Sotsialnaia doktrina rossiiskikh musulman [Social doctrine of Russian Muslims]. Available at: https://islam-today.ru/socialnaa-doktrina-rossijskih-musulman/ (accessed 21 August 2020).

14. Sergeeva, I.L. Transformatsiia massovoi kultury $v$ tsifrovoi srede [Transformation of mass culture in the digital environment.]. Culture and civilization. 2016 V. $6 \mathrm{~N} 6 \mathrm{~A} .58$ p. (in Russian).

15. Smirnov M. Yu. Tsifrovizatsiia kak "obnulenie" religii [Digitalization as "zeroing" of religions]. Available at: https://cyberleninka.ru/article/n/ tsifrovizatsiya-kak-obnuleniereligion (accessed 20 August 2020).

16. Sokolova, N.L. Tsifrovaia kultura ili kultura v tsifrovuiu epokhu [Digital culture or culture in the digital age]. International Journal of Cultural Research. 2012. No 3. 6 p. Available at: http://www.culturalresearch.ru/files/open_issues/03_2012/IJCR_03\%288\%29_2012.pd (accessed 7 September 2020). 
17. Tsifrovaia religiia. Proniknovenie tserkvi v onlain [Digital religion. Church penetration into online]. Available at: https://novate.ru/blogs/190313/22688/ (accessed 14 August 2020). 